$\begin{array}{llll}\text { Submitted } & : \mathbf{1 9 . 1 0 . 2 0 2 0} & \\ \text { Accepted } & : \mathbf{2 3 . 1 1 . 2 0 2 0} & \\ \text { Year } & : \text { December } 2020 \quad \text { Volume: } 1 \text { Issue: } 2 \\ \text { DOI } & : 10.47333 / \text { modernizm.2020265880 }\end{array}$

\title{
THE MODERNIST INFLUENCE ON QUEER VISION: MARK RAVENHILL'S MOTHER CLAP'S MOLLY HOUSE
}

\author{
Hande Dirim Kılıç¹
}

\begin{abstract}
Queer theory is one of the theories that is regarded as an outcome of postmodern condition and its philosophical questionings. Its rejection of stable gender identities develops out of post-structuralist challenges to a binary understanding of the world, while its inclusive approach to marginalised and unrepresented sexual identities is linked to postmodernism's proliferating and decentralising politics. This closely-knit connection between postmodernism and queer, however, usually shadows the deeper and less recognised legacy between modernism and queer. When the literary modernism and queer theory are re-examined side by side, it becomes possible to interpret queer as an offspring of both modernism and postmodernism. Queer theory and queer works benefit highly from modernism. Both modernism and queer present sexuality as fluid, challenge the linear and heteronormative understanding of time and both are politically assertive. This paper analyses this connection from both a theoretical and a literary perspective. Mark Ravenhill's Mother Clap's Molly House, one of the earliest queer plays of British theatre, illustrates this connection as a representative queer text with modernist undertones.
\end{abstract}

Keywords: Queer Theory, Literary Modernism, Queer Modernism, Mark Ravenhill, Gender Studies.

\section{MODERNIZMIN QUEER DÜŞÜNCE ÜZERINE ETKISİ: MARK RAVENHILL'IN MOTHER CLAP'S MOLLY HOUSE OYUNU}

\begin{abstract}
Öz
Queer kuramı postmodern durumun ve postmodernizmin sorgulamalarının bir sonucu olarak görülmektedir. Kuramın sabit cinsel kimlikleri reddi postyapısalcı düşüncenin ikili dünya görüşüne yönelik sorgulamalarından doğmuş, ötekileştirilmiş ve temsil dışı cinsel kimliklere yönelik kucaklayıcı tavrı ise postmodernizmin çoğulcu ve merkezleştirme karşıtı görüşleriyle bağlantılı olarak gelişmiş̧tir. Postmodern ve postyapısalcı kuramlar ile queer düşünce arasındaki bu yakın ilişki, çoğu zaman queer ve modernizm arasındaki derin ama çok da göz önünde olmayan bağlantıyı gölgeler. Modernist yazın ve queer kuram bir arada incelendiğinde queer düşünceyi postmodernizm kadar modernizmin de bir ürünü olarak değerlendirmek mümkün olur. Değişken cinsel kimlikleri temsil biçimleri, doğrusal ve heteronormatif zaman algısına meydan okuyuşları ve politik iddiaları bakımından queer eserler modernizmden büyük ölçüde faydalanmaktadır. Modernizm ve queer arasındaki bağlantıyı kuramsal ve edebi açılardan inceleyen bu çalışma İngiliz tiyatrosununun ilk queer eserlerinden olan Mark Ravenhill'in Mother Clap's Molly House adlı oyununu modernist öğeler içeren queer bir metin olarak ele almaktadır.
\end{abstract}

Anahtar Kelimeler: Queer Kuram, Modernizm, Queer Modernizm, Mark Ravenhill, Cinsiyet Çalışmaları.

The birth of the queer theory is usually connected to the conflict between the gay and lesbian identity politics and the post-modernist theory's questioning the inclusiveness and the reliability of existing identity categories (Beemyn and Eliason 5-6). As it developed as an independent theory, queer benefitted a lot from highly abstract and theoretical language of post-structuralism and its deconstructive philosophy (Kollias 144-147). Moreover, the theorists who are regarded as the founders of queer theory today, such as Michel Foucault, Judith Butler and Eve Kosofsky Sedgwick, were already well- established poststructuralist scholars. This closely-knit connection between poststructuralism/postmodernism and queer studies forms the foundation of queer theory; however, it may also cause the scholars to overlook the connection of queer theory and queer works to earlier

\footnotetext{
${ }^{1}$ Dr., English Language and Literature, Kocaeli University, handedrm@gmail.com, https://orcid.org/0000-00031615-4744.
} 
movements and literary traditions. One of the movements that have especially a deep connection to queer theory is modernism. Although since its emergence queer theory has been widely used to interpret modernist texts as a result of "its great strength as a tool of interpretation and politics - its flexibility and its corrosive relations with fixed identity categories" (Love 745), the influence of modernist tradition on queer theory and queer works is a topic usually neglected. The aim of this paper is to analyse this connection between modernism and queer from both a theoretical and a literary perspective. To illustrate, Mark Ravenhill's Mother Clap's Molly House (2001), one of the earliest queer plays of British theatre, will be analysed as a representative queer text with modernist undertones.

Experimentation with temporality is the first issue that is a very important feature of modernist writing and has a significant place in queer scholarship. The modernist interest in formulating a fresh outlook to time is usually traced back to French philosopher Henri Bergson. Bergson refused to think about time as a straight line but as a complicated and many-layered structure. Many modernist writers including Virginia Woolf, Michel Proust and T. S. Eliot were influenced by Bergson's theories and started to experiment with the temporal frame in their works in a way that would challenge the traditional narrative structure of realist literature (Taunton). Modernists often refused to follow a chronological order in their narration and abandoned conventional narrative stages (exposition, rising action, falling action, climax, resolution). They did not always provide their readers with a consistent point of view or character development (Haffey 4). As Kate Haffey argues, these "modernist experiments with temporality and narrative have been taken up by a number of authors writing several generations later... as a response to contemporary issues or as a defining part of their own narrative projects" (3). And one of these contemporary schools of thought that share the modernist interest in temporality is queer theory. While for modernist writers reacting to a linear and/or traditional understating of time progression is a reaction to the realist tradition, for many queer theorists it is a means of promoting a queer worldview which cannot be sufficiently represented with this traditional understanding of temporality. Despite these differences in their interests and motivations, both queer theory and literature problematize a traditional understanding of time in similar ways to the writers of the modernist tradition. These similarities can be discussed under two categories: queer theory's criticism of normative time frames that mark the life of an individual; and its criticism of a linear understanding of time in general.

In realist fiction, the normative time frames that are used to mark individual lives were presented as standard and objective structures that guided a character's transition from childhood to adulthood. Modernist tradition, on the other hand, focused on a personal understanding of time that worked against the time measured by the clock, and with the help of techniques such as stream of consciousness, modernist writers developed a perception of time which was more personal, subjective and deeply influenced by individual consciousness (Taunton). Queer scholars also worked on an individualised perception of time while theorising about the ways passage of time is experienced by queer individuals. They questioned whether the assumptions about the traditional markers of time in an individual life can apply to queer people. Judith Halberstam's definition of queer time sits at the centre of this questioning in queer scholarship. Halberstam defines queer time as "the dark nightclub, the perverse turn away from the narrative coherence of adolescence - early adulthood - marriage reproduction - child-rearing - retirement - death, the embrace of late childhood in place of early adulthood or immaturity in place of responsibility" and she states that these sort of queer temporalities require a departure from temporal frames of bourgeois reproduction and family, longevity, risk/safety, and inheritance" ("Theorizing Queer Temporalities" 182; In a Queer Time 6). With this definition, Halberstam allocates two characteristics to queer temporality: one is a rejection of "the bildungsroman structure that charts the passing of time as a progression from childhood through adolescence to mature adult heterosexuality" (Haffey 1); the other is a rejection of bourgeois values in shaping this structure.

This rather general criticism of traditional milestones in life is further developed by other queer critics in later years. In his book No Future: Queer Theory and Death Drive, Lee Edelman develops the concept of "reproductive futurism" with it, he criticises the heteronormative temporality that venerates the child as the symbol of the future, Nguyen Tan Hoang directs the criticism to 
homosexual communities and critiques their tendency to create homonormative timelines according to which coming out, settling in, finding a permanent partner are regarded as the preconditions of a desirable gay/lesbian life (185), Kathryn Bond Stockton focuses on the concept of "growing up" in her book The Queer Child, or Growing Sideways and questions its validity in the life of a queer child who may not grow up in a way that is traceable with the heterosexual timeline of maturing. Although each one of them focuses on a specific issue, all these queer writers are criticising time frames which dictate a uniform structure about the progression of individual life. The prevalence of this concern in queer scholarship shows that queer theoreticians share the modernist passion for disrupting progressive and chronological temporalities that shape individual life narratives.

Both in modernist literature and queer theory, the challenge to the progressive temporalities cannot be limited to the way these movements evaluate the structures of individual life narratives. Rather in a more general light, each discipline problematizes chronological temporalities in general. While modernist writers react against such ordered progress in literature with their refusal of chronological order in their narration or by abandoning conventional elements of plot, many queer writers react against the expectancy of an ordered timeline or linear history in a queer world. According to Carla Freccero "Queer temporality celebrates the queerness of nonprogressive, nonsequential time" and questions "the past-present-future march of time" not because such an order does not exist but because it is ideologically charged and serves a heterosexual world order (22). This criticism of linear perception of time in queer theory also can be seen as in queer theory's approach to history writing. Many queer scholars believe that queer history should be irregular and discontinuous because according to queer perception only "within the lost moments of official history, queer time generates a history of its own" and a unified and linear understanding of history closes the possibilities of uncovering queer moments hidden in the past (Freeman xi). When queer theory's resistance to linear and chronological temporality and history finds a reflection in literature in the form of queer literature, the connection between modernism and queer scholarship becomes more evident.

The work chosen as an example of queer literature for this study, Mark Ravenhill's play Mother Clap's Molly House, shows many similarities to modernist literature in terms of its narrative structure and the unconventional and irregular presentation of its characters' developmental stages. First of all, the play does not follow a traditional and linear plotline, its narrative structure is formed around historical shifts. The play continuously moves back and forth between two pivotal time periods in queer history. It opens in the eighteenth century in a dress shop which hires dresses, mostly, to prostitutes. As the story progresses, the shop is taken over by the wife of the previous owner, Mrs Tull, and is transformed into a molly house. In the middle of this transformation, the play moves to 2001 to a sex party hosted by wealthy gay men. Drug use, sex without intimacy and problematic relationships are at the centre of this party. These different settings of the play shift constantly between one another without a connection, apart from the fact that they both depict queer communities. Although each of the two separate parts of the play follows a chronological timeline, these timelines are constantly interrupted by one another. Through these interruptions, which disturb the narrative structure of the play, Ravenhill challenge a unified and coherent outlook to time. He makes his readers question the connection between the past and the present by consciously refusing to connect the two plots. Therefore, it can be argued that the temporal experiments that are perfected by the modernist writers hundred years ago to challenge the conventions of plot development are used by a queer writer today to convey his own messages.

In a similar manner, reading the two parts of the play side by side does not establish a chronological time frame in the reader's mind. The time does not seem to flow in a linear and progressive way between these two centuries. Like modernist literature's orientation toward the past (Haffey 183), the shifts between the past and the present in Mother Clap's Molly House prioritise the past over the present. The lifestyle of the emerging molly community in the eighteenth century is much more colourful and liberated than the lifestyle of the established gay community in the twentyfirst century. Ravenhill turns the perceptions about the liberation of the gay community upside down. He claims that an unliberated moment in history which is free from all sexual categorisations, definitions and hieratical positioning can be more vibrant and liberating than an allegedly liberated present that is enslaved within a fixed, normative, commercialised understanding of sexuality. Carla 
Freccero describes such an approach to history as queering time, because according to her queer time is a time that

does not follow the pattern of succession set down by progressive history, according to a logic of cause and effect. It is not the heteronormative reproductivity of time, conceived as generations succeeding generations culminating in the present and on its way to a future that will be time's fruition.... [it is] is perverse: it argues for an eccentric relation between events and their effects, and it challenges the empiricism of what qualifies as an event. (19-20)

In line with Freccero's argument, two different generations of queer people presented in the play do not seem to be connected with an ancestral tie, the past and the present stand side by side without talking to each other directly in "an eccentric relation" (20).

Experimentations with temporality in Mother Clap's Molly House are not limited to irregularities in the narrative structure of the play, characters' developments are also formulated according to "a queer temporality," to borrow Halberstam's terminology, that cannot be monitored by the traditional markers of heterosexual life (In a Queer Time 6). According to this queer temporality, a lot of characters find new identities at odd moments in their life. They follow irregular developmental paths, some leave their assigned gender identities behind with adolescence, some become mothers without giving birth, some give symbolic birth to new selves as adults. The first character who experiences life outside the conventional milestones is the title character of the play Mother Clap (or Mrs Tull as she is called at the beginning of the play). Mrs Tull is introduced to the play as a childless middle-aged woman. Soon, she loses her husband and starts a new life as a widow. Despite the limitations of being a widow in the eighteenth century and despite being at a later stage in life according to normative timelines, Tull continuously rediscovers herself and adopts new identities throughout the play. After setting up a molly house, she declares Tull as "dead and buried" and announces herself as the "Mother" of the mollies (54-55). At the end of the play, as she leaves London for a new life in the countryside, she says that she will also leave her motherhood behind and will adopt new identities as life progresses. None of the changes Tull undergoes is coherent with "temporal frames of bourgeois reproduction and family," they are all arbitrary (Halberstam In a Queer Time 6). Tull is only one of the many characters in the play who evolve and develop in a queer time frame. Amy moves from being a female prostitute to a male servant, Princes Seraphina defines himself as a man, a woman and a hermaphrodite in different parts of the play, Tull's apprentice Martin and his friend Orme start their adolescence by becoming mollies called Kitty Fisher and Susan Guzzle etc. In line with Halberstam's definition, the queer time that commands the play cannot be measured with normative time frames that are accepted in conventional heterosexual societies and characters do not follow the developmental stages of heterosexual adult.

Tull and Amy's transformations in the play also make the readers question the relationship between reproduction and temporality. For Tull, becoming a mother does not come as a result of marriage; in fact, by accepting that she cannot become a biological mother, Tull transforms herself into a mother of a new queer community (55). Similar to Tull, Amy's relationship with motherhood also take an unexpected turn. She is introduced to the play as one of the prostitutes that work with Tull. Soon, she becomes pregnant, but rather than giving birth to a baby; she decides to abort the baby and instead she gives birth to a new self, a young boy called Ned (38-70). The examples of Tull and Amy show that, in a queer timeline, becoming or not becoming a mother does not have to be defined by a "biological clock" that works in line with the heteronormative logic of reproductive temporality (Halberstam In a Queer Time 5).

In Mother Clap's Molly House, Amy's decision to abort the baby not only disturbs the linear temporality of the pregnancy-birth order but it also opens up questions about the symbolism and temporal significance of having children in a queer society. In traditional literary symbolism, the birth of a child is interpreted as hope, future or spiritual change ("child") and such a perception is in fact has its basis on a cultural perception that associates the continuation of life with the figure of child. As it is stated above, in his book No Future: Queer Theory and Death Drive, Lee Edelman criticises this perception which regards child as the symbol of the future. He calls it "the compulsory narrative of reproductive futurism" and talks about how such a perception only equates a queer man with death and 
negativity (21-22). The play shares this questioning of reproductive futurism that can be seen in Edelman's work. When Amy's pregnancy is revealed, a dispute starts in the play whether a child is a blessing or a curse (38). Prostitutes argue that it is definitely a curse for a prostitute as it will "suck the youth and the beauty and the life out of" her (38). Without attributing to it any emotional value, the fate of the baby is decided considering its effects on the business, whether the leader of the prostitutes will earn more money by aborting it, or by forcing the prostitute to keep it so that they can get a discount from Tull by abusing Tull's motherly instincts (38-40). Eventually, unbeknownst to them Amy aborts the pregnancy. Therefore, let alone being sanctified as the symbol of future, as expected from the narrative of the reproductive futurism, the baby is not even given a future. It is aborted by the mother who sees it as an obstacle for her own future. Therefore, a heteronormative celebration of reproduction as a symbol for the future is problematized.

Mother Clap's attempt to fix the relationship of Martin and Orme by organising a pregnancy game can be given as another example of the problematization of reproductive futurism in the play. Mimicking the role of a desperate heterosexual woman who regards childbirth as a way of reconnecting with her husband, Martin hopes that giving birth to a wooden doll may bring him the monogamous future he dreams with Orme (74-76). Although the baby is a wooden one in this case, hope and expectation associated with it still belong to the narrative of reproductive futurism. However, once again, this narrative is presented in the play only to be turned upside down. Orme turns away from Martin refusing both the baby and the game (76-77) and at the end of the play, the wooden baby is left behind by all characters as Tull says that there is no place for it in the trunk as they are moving away (105). This refusal of reproductive futurism in the symbol of the baby can be regarded as another example of how the conventional symbols or milestones of heteronormative temporal structures are refused by queer writers with the intention of forming their own queer temporality.

The last example to Mother Clap's Molly House's resistance to the progressive timelines of heterosexual lifestyles is the way the transition from childhood to adolescence, from adolescence to maturity occur in a unique and queer timeline in the lives of the characters. Various different examples can be given for the unconventional processes the characters follow as they develop throughout the play. For example, Tom describes the process of coming out as a way of reaching maturity for a queer individual, for him coming out is like getting on a "[t]ime machine. Two months and I've travelled hundreds years into the future. Only the future's like now. I mean, look at me. Clubs. E. Shagging all sorts of blokes. It's great" (64). His interesting approach to the passage of time requires an analysis from several different angles. First of all, the quotation shows how the perception of time can be quite subjective and how coming out is regarded as a life-changing event that feels like years, or hundred years in Tom's case. Moreover, Tom's approach to coming out indicate that among the members of queer community, the milestones, such as getting married, having kids, of heterosexual adulthood and maturity can be replaced with the events like coming out. As it is stated by Hoang, however, such an approach only replaces heteronormative timelines with homonormative timelines and guarantees a continuation of hierarchies that would continue to suppress different members of queer communities (184).

A close analysis of Tom's character development in the play also indicates how setting such progressive timelines proves problematic. As the play proceeds, it is revealed that the self-realisation Tom claims to have achieved after coming out seems to be an illusion. He feels childlike excitement for entering the queer community and excessive fear of not fitting in, to suppress these feelings he turns to drug use. In the end, when a sexual act he participates in takes an abusive and forceful turn, he breaks down:

I was really looking forward to this evening. This is all I ever wanted. All them years stuck at home listening to me dad: Fucking poofs this, fucking queers that. And I thought: You're history, you. Cos I'm a poof, but I in't telling you. Oh no. One day I'm just gonna up and go. Stick a note on the fridge. 'Fuck the family'. Little husband with his little wife and their little kids. That's history. And I'm the future. This is the future. People doing what they want to do. People being who they want to be. So why ... ? Why do you have to make it wrong? (85-6) 
This quotation shows that Tom's expectations about the homosexual lifestyle were based on his reversal of hierarchy between heterosexuality and homosexuality. However, such a view also proves to be a deception for Tom because, at its basis, it still bears the artificial binary and hierarchical worldview the queer perception tries to overthrow. While refusing reproductive futurism, which equates future with heterosexual reproduction, Tom seems to embrace homosexual futurism which gives superiority to homosexuals. This hieratical perspective works for Tom's disadvantage. The more he overvalues a homosexual lifestyle, the bigger his disillusionment gets at the end. And on a theoretical basis, his outlook fails to be a truly queer one because the strength of queer vision lies in its refusal of all kinds of linear and progressive perspectives of temporality and all sorts of hierarchical positionings. From the faults in his judgement, it can be assumed that despite coming out and rebelling against his family, Tom is still far away from being the mature and complete homosexual he claims to be.

Tom's example and the different developmental stages of many other characters in the play lead to a questioning on the nature of queer maturity: on the kind of timeline queer maturity requires, or whether events like coming out or participating in sexual acts can be counted as the conditions of adulthood in queer communities, or if maturing or becoming an adult are valid goals for the queer community to aspire. In her book The Queer Child: Growing Sideways in the Twentieth Century, Kathryn Bond Stockton also questions the ways a queer child grows and argues that during the process of coming to terms with their queerness, in the absence of role models to help them out, queer children learn to delay their growth and grow sideways $(1,3)$. This delay in growth can clearly affect the way queer adults reach maturity in adulthood and create a discourse in the society that regards the queer adulthood as a problematic state, "a state of halted growth, forever frozen in an immature stage of development" (Haffey 8).

In Mother Clap's Molly House, the passage from queer childhood to adolescence is depicted through the sexual awakening of Tull's apprentice Martin. Martin is described in the play as a young apprentice, between a boy and a man, therefore, it can be assumed that he is on the verge of adolescence. Although the long walks he takes in the cruising area called "Sadomites Walk" indicate his curiosity about same-sex activities (5-7), he only comes to terms with his sexuality when a more experienced apprentice boy, Orme, persuades him to play a game of dressing up as women (43-48). With the guidance of Orme, Martin's sexual discovery happens quicker than it would normally happen, therefore, without much delay. However, their sexual actives are described in the play in the form of games and role-plays, so Martin's sexual awakening still remains at a childlike state. With this sexual discovery, Martin reaches adolescence, but for him reaching adolescence means dressing up as a woman, assuming the identity of a girl called Susan, he even describes the transformation in his body like a girls': "Body's changing. Mother. Titties starting to grow. There's hair between my legs. And there's blood coming out of me" (52). He imagines his puberty with the signs of puberty in girls, therefore, none of his developmental stages follows a conventional structure.

In the play, this unconventional narrative of growth which does not lead to maturity in a traditional sense is not limited to Martin's transformation from a boy to molly. Many adult characters of the play also declare themselves as the children of Mother Clap once they assume a female identity (52). Therefore, with this sexual growth, they are transformed from adulthood to childhood. This transformation, however, should not only be regarded only as the symbolic assumption of family roles in a queer community. Once they assume their molly identities, these characters also enter a childlike state. They want to play games that are orchestrated by Mother, they want to be dressed by Mother. This childlike depiction of queer adults in the play is, on the one hand, a queer celebration of breaking the borders between childhood and adulthood, on the other hand, it also becomes a perfect example to queer temporality in the play. As Halberstam argues, a queer temporality should "embrace [...] late childhood in place of early adulthood or immaturity in place of responsibility" ("Theorizing Queer Temporalities" 182). In this queer vision, growing up, maturing, being complete, settling down are presented as problematic and oppressive concepts in the play and this presentation can be best observed when the two settings of the play are compared. In the twenty-first-century setting of the play, the attempt to look cool and composed puts pressure on every character and this pressure can be best observed in Tom's struggle as it is discussed at length above. In eighteenth-century setting, on the 
other hand, the characters are very fluid. Maturing, being complete is not on their agenda, on the contrary, they are constantly transformed into new selves. They are not expected to follow strict timelines as they evolve, they arbitrarily jump from one developmental stage to another, in a very similar way to the modernist temporalities "where time flows independently of those conventional milestones that make sense of life" (Haffey 4).

Another, more specific common interest modernism and queer share is that these two cultural formations maintained transgender allegory unlike any other period in literary history. During the modernist period, the interest in transgender representation was an outcome of "the historical forces [that] provoked a profound reorganization of the understanding of the categories of woman and man" and "in the early 1990s," queer theory "announced itself as an intellectual response to the limits of" the previous gay, lesbian and feminist movements that discarded any form of sexuality that did not fit into the identity categories and queer scholars become politically interested in representations of marginalised sexualities like transgender people (Heaney 6). Therefore, it would not be wrong to assume queer text's transgender presentations as a revival and also re-visitation of the modernist image under a new light. In her book The New Woman, Emma Heaney provides the readers with different transgender representations from modernist texts such as Mina Loy's The Sacred Prostitute (1914), Aldous Huxley's early novella Farcical History of Richard Greenow (1920), James Joyce's Ulysses (1922) Mae West's The Drag and The Pleasure Man (1927), Charles Henri Ford and Parker Tyler's The Young and the Evil (1933), Djuna Barnes' Nightwood (1936), Jean Genet's Notre- Damedes- Fleurs (1943). She argues that in these texts, these masculine women and feminine men were portrayed as "a significant component of [a] broader social change in the understanding of the body in the period that stemmed from a variety of scientific discoveries and technological innovations including prosthetics and plastic surgery" and this fresh outlook to the body became an allegory for the modernists and provided modernist works with a new "conceptual and aesthetic resource" (10-19). The function and the significance of transgender representation in queer text, however, differs from the modernist allegory, although in parts it also carries some allegorical significance.

The most important difference is that in the contemporary world transgender has a broader signification than it did have during the modernist period. Today, transgender is regarded as "an umbrella term, which includes a range of diverse gender identifications, including, but not restricted to, transsexual, transvestite, intersex, gender queer, female and male drag, cross-dressing and some butch/femme practices" (Hines 597) and queer theory with its all-inclusive approach regards it as its fundamental aim to give visibility to such categories that are stigmatised and marginalised by the heterosexual and homosexual community (Richardson and Seidman 3). Moreover, on a more allegorical level, transgender people represent the oppositional nature and definitional indeterminacy of queer theory. From the early days of gay liberation, with their appropriation of the behavioural codes of the opposite sex, transgender people were criticised by the homophobic groups, the assimilationist gay community and the feminists alike. As a political response to these divisive criticisms, the activities that are associated with some transgender groups such as cross-dressing or theatrical makeups and campy behaviour were embraced by drag artists, in this way, transgenderism gained an oppositional value in queer circles (Clews 89; Spargo 58, 61). Moreover, queer theory also celebrates transgenderism as the evidence of the socially constructed nature of sexual identity, Judith Butler argues that appropriation of another gender should not be regarded as an imitation of an original but as an indication that "[ $t]$ here is no 'proper' gender, a gender proper to one sex rather than another" ("Imitation and Gender Insubordination" 312).

In Mother Clap's Molly House, the representation of mollies can be regarded as an example of the celebration of the transgender representation in a queer text. In the eighteenth-century setting of the play, many adult men come to the molly house with the intention of assuming a female identity. They put on dresses, wear makeup, take female names and the way they assume female roles while they are in the molly house. The ease with which they explore, act out and celebrate their desires give the play its Dionysian nature and balance the grimness of twenty-first-century setting. This transgender representation also contributes to the play's subversion of a binary understanding of sexuality. By getting in and out of their female impersonations, transgender characters draw attention 
to the fluidity of gender categories as well as their performative nature (J. Butler, Gender Trouble 175).

One of the most fundamental similarities between modernists and the queer writers is their eagerness to challenge the existing norms. As it is very well known, the modernist writers "all deviate in interesting ways from the 19th-century realist norms on which" people "generally rely to understand the world" (C. Butler 2). In a similar way, queer writers also use literature and theory was a way of challenging the norms of the heteronormative and homonormative systems. Queer theory argues that all normative identity categories, sexual or not, serve and maintain regulatory regimes which dehumanise and marginalise people with unconventional sexualities and argues that structures and institutions that directly or indirectly influence a normative perception of gender should be vigorously resisted and challenged (Eng. et. al. 1). This political assertiveness, the attempt to make a difference and challenging the existing values are the features they definitely share with modernists (C. Butler 2). Both modernists and queer writers, despite the ambiguity and allusiveness of their techniques, have a message to convey. In modernist works, the messages can tend to be more artistically or intellectually grounded (Lunn 47-48), while in queer theory and literature, as a result of their more direct challenge to structures and institutions that influence the perception of gender, their messages are more political. Some queer writers like Mark Ravenhill, not only share this consciousness to make a change with modernists, but they also borrow modernist techniques in this attempt to make a change.

To strengthen his political message Ravenhill uses the elements from epic theatre tradition, developed by the modernist Marxist writer Bertold Brecht. By using various different techniques that would upset a realistic representation, (such as historicisation, actors playing multiple characters, the montage of discontinuous scenes, using songs or long dialectical speeches, signposts etc.), Brecht aimed to create an "alienation"/"estrangement"/"defamiliarisation" effect on his audiences which would "help audiences, not to 'consume' the work, but to step back to reflect upon the political significance of the characters in the story, rather than to identify with and feed on their feelings as individuals" (Butler 9). Ravenhill uses several of Brecht's epic theatre techniques. Through historicisation, he aims to lead his audience to an indirect questioning of the connection between the past and the present. Through use of songs such as "The Widow Carries On" (18), "The "Prentice Led Astray" (27), "A Bargain With A Whore" (35) and "The Widow Finds New Trade" (41), he "interrupt[s] the flow of the action and provide[s]" an extra commentary on the events and the themes in the play (Bradley 36, Barnett 72). Through "clear dialectical arguments set up throughout the narrative," he forces his characters to take an intellectual stance towards their own conditions (Saunders 179) and by double casting the characters in both the eighteenth-century and the twentyfirst-century settings of the play, he decreases the emotional connection between the characters and the audience. Moreover, the elements of epic theatre employed in Mother Clap's Molly House can be regarded as a modernist expression of "hostility to 'bourgeois' notions of sympathy and involvement, as associated with traditional realism" (C. Butler 9).

Although in academic circles queer theory is categorised as a branch of postmodernist and poststructuralist studies, in terms of its problematization of chronological and normative temporalities, its representation of marginalised sexualities such as transgender people and its challenge to social and political norms, queer bears a strong resemblance to modernist literature. In light of these findings, it can be argued that despite the long time span between these two movements, modernism and queer theory should not be thought of as disconnected disciplines. The works of writers like Mark Ravenhill overcome such temporal divides and show that even the most distant traditions can continue to influence one another. While past traditions like modernism still influence contemporary schools of thoughts like queer studies with the ideas and techniques they provide, the current trends and viewpoints will always enrich the ways the past traditions are interpreted.

\section{WORKS CITED}

Beemyn, Brett, and Mickey Eliason. Queer Studies: A Lesbian, Gay, Bisexual, and Transgender Anthology. New York: New York UP, 1996.

Butler, Judith. Gender Trouble: Feminism and the Subversion of Identity. New York: 
Routledge, 1990.

---. "Imitation and Gender Subordination." Henry Abelove et. al., eds. The Lesbian and Gay

Studies Reader. New York: Routledge, 1993. 307-320

Butler, Christopher. Modernism: A Very Short Introduction. New York, Oxford UP, 2010.

“Child.” Juan E. Cirlot. A Dictionary of Symbols, London: Routledge, 2001.

Clews, Colin. Gay in the 80s: From Fighting for Our Rights to Fighting for Our Lives.

London: Troubador 2017. Ebrary. Web. 20 May 2020.

Cook, Matt, ed. A Gay History of Britain: Love and Sex Between Men since Middle Ages. Oxford: Greenwood, 2007.

Edelman, Lee. No Future: Queer Theory and Death Drive. Durham and London: Duke UP, 2004.

Eng, David L. et. al. What's Queer About Queer Studies Now? Durham, NC: Duke UP, 2005.

Freccero, Carla. "The Queer Time of Lesbian Literature: History and Temporality." The Cambridge Companion to Lesbian Literature. Cambridge: Cambridge UP, 2005.

Freeman, Elizabeth. Time Binds: Queer Temporalities, Queer Histories. Durham and London: Duke UP, 2010.

Haffey, Kate. Literary Modernism, Queer Temporality: Eddies in Time. Switzerland: Palgrave McMillan, 2019.

Halberstam, Judith. In a Queer Time and Place: Transgender Bodies, Subcultural Bodies. New York: New York UP, 2005.

---. "Theorizing Queer Temporalities: A Roundtable Discussion" GLQ A Journal of Lesbian and Gay Studies. 13 (2007): 177-195. Web. 3 June 2020.

Heaney, Emma. The New Woman Literary Modernism, Queer Theory, and the Trans Feminine Allegory. Evanston, Illinois: Northwestern UP, 2017.

Hines, Sally. “Queerly situated? Exploring Negotiations of Trans Queer Subjectivities at Work and within Community Spaces in the UK." Gender, Place and Culture. 17.5 (2010): 597-613. Web. 3 June 2020.

Hoang, Nguyen Tan. “Theorizing Queer Temporalities: A Roundtable Discussion” GLQ A Journal of Lesbian and Gay Studies. 13 (2007): 177-195. Web. 3 June 2020.

"Homosexuality." The Oxford Dictionary of Gender Studies. 1st ed. Oxford: Oxford UP, 2017. Google Book Search. Web. 3 June 2020.

Kollias, Hector. "Queering it Right, Getting it Wrong." Queer Theory's Return to France. Edinburg: Edinburgh UP, 2012.

Love, Heather. "Introduction: Modernism at Night." PMLA 124. 3 (2009): 744-748. JSTOR. 
Web. 10 June 2020.

Lunn, Eugene. Marxism and Modernism, an Historical Study of Lukács, Brecht, Benjamin and Adorno. Berkley: U of California P, 1982.

Ravenhill, Mark. Mother Clap's Molly House. London: Methuen, 2001.

Richardson, Diane and Steven Seidman. "Introduction." Handbook of Lesbian and Gay

Studies. Ed. Diane Richardson and Steven Seidman. London: Sage, 2002. 1-13

Spargo, Tamsin. Foucault and Queer Theory. Cambridge: Icon, 2009. Print.

Stockton, Kathryn Bond. The Queer Child, Or Growing Sideways in the Twentieth Century. Durham and London: Duke UP, 2009.

Taunton, Matthew. "Modernism, Time and Consciousness: The Influence of Henri Bergson and Marcel Proust.” British Library. 25 May 2016. Web. 14 May 2020. 